\title{
NACIONALISMO, XENOFOBIA E UNIÃO EUROPEIA: BARREIRAS À LIVRE CIRCULAÇÃO DE PESSOAS E AMEAÇAS AO FUTURO DO BLOCO EUROPEU
}

\section{NATIONALISM, XENOPHOBIA AND EUROPEAN UNION: BARRIERS TO THE FREE MOVEMENT OF PEOPLE AND THREATS TO THE EUROPEAN BLOC'S FUTURE}

\author{
Vitória Volcato da Costa \\ Universidade do Vale do Rio dos Sinos - Unisinos - (Porto Alegre, RS, Brasil) \\ Luciane Klein Vieira \\ Universidade do Vale do Rio dos Sinos - Unisinos - (Porto Alegre, RS, Brasil)
}

Recebimento: 20 mar. 2019

Aceitação: 15 ago. 2019

\begin{abstract}
Como citar este artigo / How to cite this article (informe a data atual de acesso / inform the current date of access):
COSTA, Vitória Volcato da; VIEIRA, Luciane Klein. Nacionalismo, xenofobia e União Europeia: barreiras à livre circulação de pessoas e ameaças ao futuro do bloco europeu. Revista da Faculdade de Direito UFPR, Curitiba, PR, Brasil, v. 64, n. 3, p. 133-160, set./dez. 2019. ISSN 2236-7284. Disponível em: <https://revistas.ufpr.br/direito/article/view/65536>. Acesso $\quad$ em: $11 \quad 2020 . \quad$ mar. 201 :
\end{abstract} http://dx.doi.org/10.5380/rfdufpr.v64i3.65536.

\section{RESUMO}

O aumento dos fluxos migratórios, nos últimos anos, desencadeou a denominada "crise migratória”, causando crescimento do nacionalismo e da xenofobia na Europa. Nesse contexto, barreiras à livre circulação de pessoas entre os Estados membros da União Europeia começam a ser observadas com maior frequência e intensidade, e o euroceticismo ganha força. Diante disso, este artigo visa investigar a história da livre circulação dos cidadãos europeus e a trajetória da política migratória para imigrantes extra comunitários. Igualmente, pretende-se analisar o surgimento do sentimento nacionalista e da xenofobia, e em que medida seu aumento pode contribuir para o euroceticismo, constituindo-se inclusive em ameaça ao futuro do bloco europeu. Assim, busca-se responder à seguinte indagação: o crescimento do nacionalismo e da xenofobia pode levar a um enfraquecimento da integração na União Europeia? Para encontrar a resposta utilizou-se, como metodologia de pesquisa, a revisão bibliográfica e a análise documental, valendo-se dos métodos histórico, comparativo e normativo-descritivo. Os resultados demonstram que a política migratória desenvolvida contém aspectos herdados do colonialismo, devido aos quais a xenofobia impera, e que, no contexto da crise migratória, contribuem para a imposição de barreiras à livre circulação de pessoas. Ainda, em razão dos sentimentos nacionalista e xenofóbico que crescem com a crise migratória, o euroceticismo ganha força, influenciando fenômenos como o Brexit e levando Estados membros como a Itália a cogitarem a saída da União Europeia.

PALAVRAS-CHAVE

Livre circulação de pessoas. Nacionalismo. Política migratória. União Europeia. Xenofobia. 


\begin{abstract}
The increase of migration flows unleashed, in the last years, the so called "migration crisis", resulting in a nationalist and xenophobic growth in Europe. In this context, barriers to the free movement of people in the member states of European Union can be observed with more frequency and intensity, as well the euroscepticism it is strengthened. Therefore, this article aims to investigate the history of the free movement of European citizens and of the migration policy to non-communitarian immigrants. At the same time, it aims to analyze the origin of nationalism and xenophobia in the European societies, and how its growth can both contribute to the euroscepticism, and even turn into a threat to the European bloc's future. Therefore, this article pursues to answer the following question: can nationalism and xenophobia growth contribute to a weakening of the European Union integration? As a research method, this investigation used the bibliographical review and the documental analysis, by means of historical, comparative and normative-descriptive procedures. The results exhibit that the migration policy has aspects inherited from colonialism, which is why xenophobia is present and, in a migration crisis context, contribute to the imposition of barriers to the free movement of people. Also, due to the nationalist and xenophobic sentiments that grow with the migratory crisis, euroscepticism gains strength, influencing phenomena like Brexit and leading member states like Italy to consider leaving the European Union.
\end{abstract}

\title{
KEYWORDS
}

Free movement of people. Nationalism. Migration Policy. European Union. Xenophobia.

\section{INTRODUÇÃO}

A União Europeia (UE) é o sistema de integração mais exitoso do mundo, o qual é utilizado como modelo para blocos de outros continentes, principalmente em razão da adoção da supranacionalidade ${ }^{1}$. Ao longo dos anos, o bloco tem "comunitarizado" cada vez mais diversos setores, o que confere autonomia à UE para decidir sobre grande parte dos assuntos (NEGRO, 2010, p. 43-44). A partir da reforma dos tratados constitutivos operada pelo Tratado de Lisboa, também foi “comunitarizado” o setor da Política Exterior e de Segurança Comum (PESC), o qual trata da política migratória e estava historicamente inserido no pilar intergovernamental do bloco (SILVA; AMARAL, 2013, p. 235-259).

Apesar desta reforma, há uma crescente onda xenofóbica e nacionalista que vem sendo observada em diversos países da UE. Registre-se que o nacionalismo que é tratado no presente artigo tem relação intrínseca com a questão do sentimento de apego dos cidadãos nacionais em relação à nação, conforme explicado por Benedict Anderson, com raízes culturais profundas sobre as quais o nacionalismo surge na modernidade, com a formação dos Estados-Nação na Europa do século XVIII (ANDERSON, 2008, p. 30-34). Ainda, tendo em vista que esse sentimento nacionalista foi moldado

\footnotetext{
${ }^{1}$ Não há consenso acerca de um conceito determinado de supranacionalidade, porém, há características comuns nos processos de integração que apresentam traços de supranacionalidade. A principal característica é a cessão de soberania dos Estados membros para a comunidade, o que dá ao espaço integrado maior autoridade governamental e legislativa sobre seus Estados membros.
} 
ao longo da história para diferentes políticas e ideologias, aqui será trabalhado com um fenômeno que vem ocorrendo na atual década, referente a um nacionalismo presente em discursos populistas de extrema direita, que trata de uma ideia de Estado-Nação como propriedade. Uma vez que esta propriedade pertence aos cidadãos nacionais, o sentimento de apego a seu Estado-Nação faz com que passem a se enxergar como proprietários deste, devendo defendê-lo do estranho - o estrangeiro (FIGUEIRA, 2018).

Assim, o sentimento xenófobo também se encontra intrinsecamente relacionado com o nacionalista, mas pode ir além. Isso porque a xenofobia se intensifica em razão das diferenças étnicas, culturais, religiosas, etc., o que é ampliado em relação aos imigrantes do Sul Global. Isso pode ser explicado pela colonialidade, conceito-chave do Pensamento Descolonial, e pelos discursos desumanizantes proferidos no período colonial, que seguem pautando as relações entre o Norte Global e o Sul Global sob diferentes formas de discriminação, entre elas a xenofobia.

Tal contexto ganhou força a partir do aumento dos fluxos migratórios nos últimos anos, que levou à chamada "crise migratória”. De acordo com os dados apresentados no Relatório Tendências Globais do Alto Comissariado das Nações Unidas para Refugiados (ACNUR), o número de migrantes forçados já chegou a 70,8 milhões, e segue aumentando há uma década (ACNUR, 2018, p. 4).

Diante desse cenário, o presente estudo visa responder à seguinte questão: a crescente onda nacionalista e xenofóbica pode contribuir, além de outros fatores já existentes, para que haja um enfraquecimento do nível de integração na UE? A hipótese é a de que os sentimentos nacionalista e xenofóbico contribuem, em maior ou menor medida, para levar os países ao fechamento de suas fronteiras. Ainda, esse fenômeno acaba por estimular os Estados a perseguirem seus interesses nacionais no tema migratório. Isso tudo já é suficiente para promover um abalo no processo de integração europeu. Ademais, em função do exposto, caso haja alguma ameaça a essas questões nacionalistas, poderá haver o desenvolvimento de uma inclinação dirigida à desvinculação do bloco.

A partir do problema de pesquisa apresentado, na primeira parte deste escrito será investigada a história da livre circulação dos cidadãos europeus e a trajetória da política migratória para imigrantes extra comunitários. Já na segunda parte, será analisado o surgimento do sentimento nacionalista e em que medida o aumento deste e da xenofobia, em tempos de crise migratória, podem contribuir para o incremento do euroceticismo e constituir-se em ameaça ao futuro do bloco europeu. Para os fins do presente artigo, utilizar-se-ão os métodos histórico, comparativo e normativodescritivo. Ainda, a pesquisa é qualitativa e utiliza como técnica a revisão bibliográfica e a análise documental. 


\section{A LÓGICA XENÓFOBA DA POLÍTICA MIGRATÓRIA PARA IMIGRANTES EXTRA COMUNITÁRIOS E AS BARREIRAS À LIBERDADE DE CIRCULAÇÃO DOS CIDADÃOS EUROPEUS}

Nesta primeira parte do artigo serão tratadas a livre circulação de pessoas e a construção da cidadania europeia, tanto para compreender sua importância para a integração na Europa, quanto o seu impacto sobre a lógica xenófoba construída para a política migratória aplicada aos imigrantes extra comunitários. Igualmente, será analisada a trajetória dessa política, desde a inserção do tema na integração europeia até o contexto da última década, influenciado pela “crise migratória”. Por fim, a partir do cenário apresentado, serão investigadas as heranças do colonialismo e sua influência na xenofobia europeia contra os imigrantes de terceiros Estados, a fim de compreender como se dá o surgimento desta, que está diretamente relacionada com a formação do Estado-Nação e o nacionalismo, e por que ela se dá de maneira diversa em relação àqueles imigrantes provenientes do Sul Global.

\subsection{A LIVRE CIRCULAÇÃO DE PESSOAS E SUA IMPORTÂNCIA PARA A INTEGRAÇÃO EUROPEIA}

O processo de integração na Europa inicia com a assinatura do Tratado de Paris, em 1951, o qual criou a Comunidade Europeia do Carvão e do Aço (CECA), formada por França, Alemanha, Itália, Bélgica, Holanda e Luxemburgo. Já em 1957, com o objetivo de criar uma política econômica comum, foi assinado o Tratado de Roma, constitutivo da Comunidade Econômica Europeia (CEE), e o tratado constitutivo da Comunidade Europeia de Energia Atômica (EURATOM), a fim de promover o uso da energia nuclear para fins pacíficos (ACCIOLY, 1996, p. 32).

Desde o princípio desse processo, quando da criação da CECA, havia aspectos que exigiriam a criação de um mercado comum, pois a integração de setores básicos da economia, carvão e aço, demandaria uma maior integração econômica e, posteriormente, política (BATISTA, 1998, p. 136). E, para formar um mercado comum, a livre circulação de pessoas é medida essencial. Assim, em 1957, o Tratado de Roma já previa a livre circulação de trabalhadores e a liberdade de estabelecimento (ROJAS-ROMAGOSA; BOLLEN, 2018, p. 5).

Em 1985, foi firmado o Acordo de Schengen, entretanto, este não veio como parte integrante do direito comunitário europeu, mas foi firmado por países que também integravam o sistema referido, todos em torno do objetivo comum de suprimir as fronteiras internas entre si, bem como motivados a lidar com problemas semelhantes de imigração e segurança. Apesar de assinado em 1985, entrou em vigor somente em 1995. Posteriormente, outros países aderiram, contando o Acordo 
com 22 dos 28 Estados membros da UE, na atualidade, mais quatro países que não fazem parte do sistema comunitário, que são Islândia, Listenstaine, Noruega e Suíça (EUR-LEX, 1985; ROJASROMAGOSA; BOLLEN, 2018, p. 5).

Paralelamente, no âmbito comunitário, foi firmado, em 1986, o Ato Único Europeu (AUE), que veio com o objetivo de formar um mercado comum, acrescentando, portanto, ao tratado constitutivo das Comunidades Europeias, a cooperação entre os Estados membros para implementar a livre circulação de pessoas, suprimindo as fronteiras internas (BATISTA, 1998, p. 158). O AUE foi firmado por Bélgica, Dinamarca, Alemanha, Grécia, Espanha, França, Irlanda, Itália, Luxemburgo, Países Baixos, Portugal e Reino Unido, e logo submetido à ratificação dos Estados (EUR-LEX, 1987).

Quarenta anos depois do Tratado de Paris, criou-se finalmente a União Europeia, por meio do Tratado de Maastricht ou Tratado da União Europeia (TUE), de 1992, o qual tem como objetivo formar uma união econômica e monetária² ${ }^{2}$ Para atingir tal objetivo, instituiu a cidadania europeia. Essa cidadania veio prevista no art. 8 do TUE, e abrange o direito de livre circulação e de estabelecimento dentro do território da UE. Aos cidadãos europeus também são atribuídos direitos políticos - votar e ser votado - e direito de acesso à justiça comunitária - reclamar em juízo por violação de seus direitos fundamentais dentro da União, tendo como base a Convenção Europeia para a Proteção dos Direitos do Homem e das Liberdades Fundamentais ${ }^{3}$, de 1950 (BATISTA, 1998, p. 138-145).

Isso ocorreu porque, a partir das exigências do mercado comum, etapa prévia necessária para instituir a união econômica e monetária, as normas heterogêneas dos Estados membros mostraramse insuficientes para proteger os trabalhadores europeus.

Não obstante, cabe registrar que o direito à livre circulação nos Estados membros da UE é distinto daquele vigente nos Estados que integram o Espaço Schengen. A livre circulação de pessoas é um direito de todo cidadão de um Estado membro do bloco, incluído o direito de trabalhar e residir em outro Estado membro. Já aqueles países que aderem ao Espaço Schengen, eliminam por completo suas fronteiras internas, estando no Acordo tanto Estados membros da UE quanto países europeus que não fazem parte desta. Da mesma forma, há Estados membros desta última que, por serem

\footnotetext{
${ }^{2}$ A fim de que se forme uma união econômica e monetária, é necessário que já tenha sido implementado um mercado comum, o qual impõe a livre circulação de mercadorias, pessoas, investimentos e serviços. Além dessa livre circulação, na união econômica e monetária o objetivo é que todos os Estados membros tenham uma moeda comum e respondam a um Banco Central comum.

${ }^{3}$ Assinada e ratificada por Albânia, Andorra, Armênia, Áustria, Azerbaijão, Bélgica, Bósnia e Herzegovina, Bulgária, Croácia, Chipre, República Checa, Dinamarca, Estônia, Finlândia, França, Geórgia, Alemanha, Grécia, Hungria, Islândia, Irlanda, Itália, Letônia, Listenstaine, Lituânia, Luxemburgo, Malta, Mônaco, Montenegro, Países Baixos, Noruega, Polônia, Portugal, República de Moldova, Romênia, Rússia, São Marino, Sérvia, Eslováquia, Eslovênia, Espanha, Suécia, Suíça, Iugoslávia, Turquia, Ucrânia e Reino Unido.
} 
integrantes do bloco, adotam o direito à livre circulação, porém, não fazem parte do Espaço Schengen, como é o caso do Reino Unido (ROJAS-ROMAGOSA; BOLLEN, 2018, p. 1, 5-6).

\subsection{A CONTROVERSA POLÍTICA MIGRATÓRIA PARA IMIGRANTES EXTRA COMUNITÁRIOS E SUA RELAÇÃO COM A LIBERDADE DE CIRCULAÇÃO DOS CIDADÃOS EUROPEUS}

A partir da vigência do Acordo de Schengen, foram estabelecidas três linhas de ação: controle policial, econômico e de circulação de pessoas. No que tange a este último, o Acordo, além de determinar a harmonização das legislações nacionais quanto à restrição dos controles fronteiriços para cidadãos dos Estados signatários, também determina que estes tomem medidas de segurança para coibir a "imigração ilegal” em relação a nacionais de terceiros Estados (BATISTA, 1998, p. 157).

A partir da criação do Espaço Schengen, então, houve forte cooperação entre os serviços policiais e judiciais desses Estados, a fim de eliminar as fronteiras internas. De outro lado, criou-se uma burocracia extrema, mediante a exigência de rígidos requisitos para concessão de visto e circulação temporária aos imigrantes de terceiros Estados, a fim de dificultar a entrada destes e “selecionar” quem estava “apto” a circular pelo território europeu (SILVA; AMARAL, 2013, p. 235259).

Logo, a cidadania europeia aprofunda a abertura das fronteiras internas para a livre circulação de pessoas, mas ao mesmo tempo fecha as fronteiras externas. Isso implementa um sistema comunitário que é livre e democrático para os cidadãos europeus - que deixam de ser imigrantes a partir da abertura das fronteiras internas -, mas que ao mesmo tempo é rígido e oneroso para o resto do mundo - para os imigrantes extra comunitários (SILVA; AMARAL, 2013, p. 238). Assim, a ausência de um foco voltado aos direitos humanos na questão da livre circulação de pessoas fez com que a cidadania europeia resultasse na "desigualdade e discriminação contra o não-comunitário” (BATISTA, 1998, p. 169).

A respeito, então, do histórico da política migratória europeia desenvolvida para imigrantes de terceiros Estados, o Tratado de Maastricht, que veio com o objetivo de implementar a cidadania europeia e a livre circulação desses cidadãos no território europeu, trouxe alterações nos setores que lidam com a política migratória, que são a PESC e a Cooperação em Justiça e Assuntos do Interior (CJAI). Tais setores foram inseridos no pilar intergovernamental da UE, bem como mantidos fora do âmbito de competência do Tribunal de Justiça da União Europeia (TJUE) (BATISTA, 1998, p. 139- 
140), o que representa, desde já, um tratamento problemático do assunto, porquanto os Estados escolheram manter o tema migratório completamente subordinado aos interesses nacionais.

Dentro do pilar intergovernamental, pode ser citado como passo inicial o Tratado de Amsterdã, de 1997, que estabeleceu tal política por meio da execução de programas quinquenais, como o Programa de Tampere e o Programa de Haia. Ambos os programas trataram a questão migratória como um problema para a UE, estabelecendo para as migrações uma gestão em dois pilares: garantir a liberdade de circulação para cidadãos europeus e ao mesmo tempo adotar medidas de segurança para os imigrantes extra comunitários, somente permitindo a estes a circulação pelo território europeu e a integração social, caso demonstrada a regularidade administrativa (SILVA; AMARAL, 2013, p. 239).

Com a reforma do Tratado de Lisboa, firmado em 2007 e com vigência a partir de 2009, os mencionados setores que cuidam da política migratória, PESC e CJAI, foram retirados do pilar intergovernamental (PARLAMENTO EUROPEU, 2018), passando a CJAI, desde 2014, ao âmbito de competência do TJUE (EUROPEAN COMISSION, 2014). A partir da inserção de tais setores no pilar supranacional da UE, a política migratória passou a fazer parte do processo de codecisão - hoje conhecido como processo legislativo ordinário - do Parlamento Europeu, que cuida dos interesses dos cidadãos europeus na produção legislativa, e do Conselho, que representa os interesses dos Estados membros (HAMPSHIRE, 2016, p. 537).

Entretanto, os aspectos xenófobos de uma política migratória restritiva em relação a imigrantes de terceiros Estados permaneceram mesmo após a "comunitarização" do tema pelo Tratado de Lisboa. Assim, a primeira produção legislativa realizada pelo processo de codecisão foi a Diretiva 2008/115/CE do Parlamento Europeu e do Conselho, que ficou conhecida como Diretiva de Retorno (HAMPSHIRE, 2016, p. 539). Esta foi criada com o objetivo de fazer retornar ao país de origem todo imigrante que esteja ilegalmente no território europeu ou que não cumpra com os requisitos para a concessão de refúgio. Entretanto, a Diretiva também permite que mesmo aquele imigrante que ingressou de forma regular ou teve reconhecido seu status de refugiado possa perder este direito a qualquer momento, de acordo com os critérios de cada Estado membro. Logo, milhares de pessoas, entre elas crianças, já foram retornadas e até mesmo aprisionadas enquanto se dá o processo de retorno. Isso representa o símbolo da xenofobia europeia (PEREIRA, 2014, p. 84-86).

Ainda, mesmo após o Tratado de Lisboa, a UE seguiu não interferindo nos interesses nacionais dos Estados membros em relação à admissão ou não de imigrantes em seus territórios. O que a UE fez foi apenas estabelecer direitos básicos para aqueles imigrantes que já foram admitidos pelos Estados (HAMPSHIRE, 2016, p. 540). Nesse sentido, ainda em 2008, foi firmado o Pacto 
Europeu sobre Imigração e Asilo, principal instrumento normativo da UE sobre o tema, o qual delineia a política do bloco na gestão das migrações extra comunitárias. Esse pacto possui mecanismos de execução, com objetivos de controle de migrações e de luta contra a "clandestinidade" (SILVA; AMARAL, 2013, p. 237, 241), ou seja, utilizando-se de um questionamento que criminaliza a migração.

A partir disso, a política migratória europeia apresenta três eixos, conforme Joaquín Arango (2005, p. 18): o controle dos fluxos de população, a integração social de migrantes e a cooperação para o desenvolvimento. Os resultados da aplicação desses eixos variam conforme a experiência migratória, legislação e interesses nacionais de cada Estado membro.

Com relação ao controle de fluxos de população, este ocorre tanto na origem como no destino dos fluxos migratórios. Nesse primeiro eixo, os Estados membros estabelecem critérios de seleção para aqueles migrantes desejados em seu território. Nesse sentido, o visto é um importante instrumento de controle e seleção. Para concessão de um visto apenas de turismo, são exigidos requisitos como: atestados médicos de aptidão física e mental, ausência de antecedentes criminais, demonstração de capacidade financeira, etc. O cumprimento de tantos requisitos rígidos muitas vezes não depende somente da pessoa que quer migrar, mas também da condição de seu país de origem (SILVA; AMARAL, 2013, p. 241-245).

O visto é instrumento de seleção, pois tais requisitos são exigidos somente de algumas nacionalidades e não de outras. De acordo com o Regulamento 539/2001 do Conselho, o qual fixa, em seu anexo I, a lista dos terceiros países cujos nacionais estão sujeitos à obrigação de visto, e aqueles que estão isentos de tal obrigação (em seu anexo II), verifica-se que a lista do anexo I ${ }^{4}$ é representada pela maioria dos países da África, Oriente Médio, Ásia e América Central e do Sul, sendo em grande parte as nações mais pobres de tais regiões; já a lista do anexo II $^{5}$ é representada por países situados no continente europeu e que não são membros da UE, na América do Norte, na Oceania, bem como alguns dos países mais ricos da Ásia e da América Central e do Sul (EUR-LEX, 2001).

\footnotetext{
${ }^{4}$ Afeganistão, África do Sul, Angola, Antígua e Barbuda, Arábia Saudita, Argélia, Arménia, Azerbaijão, Bahamas, Bangladesch, Barbados, Barém, Belize, Benim, Birmânia, Bósnia e Herzegovina, Botsuana, Burquina Faso, Burundi, Butão, Cabo Verde, Camarões, Camboja, Catar, Cazaquistão, Chade, Colômbia, Comores, República Democrática do Congo, Costa do Marfim, Cuba, Domínica, Egito, Emirados Árabes Unidos, Eritreia, Etiópia, Filipinas, Gabão, Gâmbia, Gana, Granada, Guiana, Guiné, Guiné-Bissau, Guiné Equatorial, Haiti, etc.

${ }^{5}$ Andorra, Argentina, Austrália, Bolívia, Brasil, Brunei, Bulgária, Canadá, Chile, Chipre, Coreia do Sul, Costa Rica, Croácia, Equador, Eslováquia, Eslovénia, Estados Unidos, Estónia, Guatemala, Honduras, Hungria, Israel, Japão, Letónia, Lituânia, Malásia, Malta, México, Mónaco, Nicarágua, Nova Zelândia, Panamá, Paraguai, Polónia, República Checa, Roménia, Salvador, São Marino, Singapura, Suíça, Uruguai, Vaticano, Venezuela.
} 
Ademais deste controle de fluxos migratórios na origem, também se registra no destino um controle policial nas zonas transfronteiriças da Europa, o qual é realizado principalmente pela Frontex, agência de fronteiras da UE, que organiza operações nas fronteiras marítimas e terrestres, em cooperação com os controles externos dos Estados membros (HAMPSHIRE, 2016, p. 539).

Em relação ao segundo eixo da política migratória - a integração dos imigrantes -, este encontra problemas pela falta de supranacionalidade no tema. A normativa da UE busca estabelecer que a integração seja bidirecional, ou seja, que ocorra tanto a inserção do imigrante na cultura europeia, como também que a sociedade europeia aprenda sobre essa cultura estrangeira e a considere. No entanto, os Estados membros estabelecem políticas nacionais que visam impor ao imigrante a cultura e religião europeia, somadas às identidades nacionais, sem considerar a aprendizagem da cultura estrangeira e os benefícios que esta pode trazer. A exemplo disso, cita-se a lei de imigração alemã, a qual visa a simples adaptação do imigrante, que é submetido obrigatoriamente a um regime rígido de aprendizado do idioma, cultura, história e sistema político alemão. Tudo isso faz com que as políticas de integração europeias não obtenham êxito (SILVA; AMARAL, 2013, p. 244-248).

Ademais, as políticas de integração são voltadas somente àqueles que tenham residência legal, sejam potenciais migrantes a possuir residência legal ou tenham direito a refúgio e outras formas de proteção internacionais reconhecidas pela UE (JUAN, 2016, p. 103). Por conta disso, um grande volume de imigrantes que se encontra em território europeu acaba por ficar completamente excluído.

Com relação ao terceiro eixo da política migratória europeia, a chamada dimensão externa dessa política, ocorre mediante a cooperação da UE com terceiros Estados, tendo recebido o nome de Abordagem Global para a Migração e a Mobilidade. A partir dessa cooperação, são oferecidos incentivos a terceiros Estados, como a facilitação de vistos, em troca de controle rígido nas fronteiras, a fim de que aqueles que pretendem migrar sem possuir algum tipo de visto ou autorização de residência, nem cheguem a alcançar as fronteiras externas da Europa. Ou seja, o maior objetivo desse eixo segue sendo o combate à migração irregular (HAMPSHIRE, 2016, p. 540).

Verifica-se, portanto, que mesmo após a reforma realizada pelo Tratado de Lisboa, que entrou em vigor em 2009, as migrações internacionais seguiram sendo tratadas como um problema para a UE, reduzindo a política comum a medidas para combater a imigração irregular, ou seja, criminalizando a migração. O enfoque dado às migrações pela UE, a partir de uma visão xenófoba, produziu resultados incompatíveis com os princípios humanitários sustentados pelo bloco, bem como trouxe violações a direitos internacionalmente reconhecidos, implementando um rígido sistema de 
controle das fronteiras sob a lógica de proteção dos cidadãos europeus (SILVA; AMARAL, 2013, p. 237, 240).

Com a inauguração de fluxos migratórios mais intensos no começo desta década, inicialmente em 2011, em razão do cenário pós-Primavera Árabe, a política migratória europeia começa a entrar em colapso. Isso porque, primeiramente, os Estados membros começaram a entrar em conflito com as instituições europeias, especialmente devido às alterações do Tratado de Lisboa, a fim de conter a interferência das instituições comunitárias nos interesses nacionais relativos ao tema da migração. Uma das interferências da UE que mais gerou conflito com os Estados membros foi a determinação de cotas de admissão de imigrantes e compartilhamento de responsabilidades com os países de entrada dos fluxos, assunto que até então era de competência exclusiva dos Estados. Segundo, os Estados membros começaram a entrar em conflito entre si, em razão da divergência de interesses nacionais e posições no tema migratório (HAMPSHIRE, 2016, p. 537, 542-543). Tais conflitos surgem a partir da elaboração de um novo plano para a política migratória, apresentado pela UE após o aumento dos fluxos.

Assim, começam a ficar cada vez mais evidentes os impactos da lógica xenófoba em relação aos imigrantes extra comunitários na livre circulação dos cidadãos europeus. Nesse sentido, um conflito entre Itália e França ocorreu em 2011, em razão de as autoridades italianas terem concedido permissão de viagem para imigrantes tunisianos sem documentos, tendo em mente que estes iriam migrar para o território francês. Em razão disso, a França reestabeleceu o controle das fronteiras internas, bem como o presidente francês à época, Nicholas Sarkozy, fez uma declaração de que a Zona Schengen não estava mais funcionando (HAMPSHIRE, 2016, p. 546).

Ainda, em 2012, houve a suspensão temporária do Acordo de Schengen por parte da França e da Alemanha, a fim de evitar a imigração irregular, sem consulta prévia ao Parlamento Europeu e ao Conselho. Isso representou uma forte ameaça ao bloco, pois reforçou o debate acerca da viabilidade da liberdade de circulação de pessoas, bem como fragilizou a supranacionalidade da UE (SILVA; AMARAL, 2013, p. 243-244). Assim, ministros do interior de diversos países europeus começaram a reivindicar a alteração das regras do Acordo de Schengen, em razão dos fluxos migratórios (HAMPSHIRE, 2016, p. 546). Em seguida, no ano de 2013, foram inseridos ao Acordo artigos que permitem a suspensão temporária e o restabelecimento do controle das fronteiras internas por parte dos Estados membros, em caso de “séria ameaça à segurança interna” (EUROPEAN COMISSION, 2019), previsão extremamente genérica e que pode ensejar sua utilização de forma arbitrária. 
Tal cenário prossegue mesmo com os novos planos da política migratória europeia, em uma tentativa de resposta ao aumento exacerbado dos fluxos, que se intensificaram ainda mais a partir de 2015, quando a crise tomou novas proporções. A resposta elaborada e que vem sendo desenvolvida pela UE e seus Estados membros, desde esta data até a atualidade, baseia-se em três objetivos centrais: (i) a reforma do Sistema Europeu Comum de Asilo; (ii) o reforço das fronteiras externas da UE; (iii) o reforço da cooperação externa da UE no tema migratório (ATASSANOV; RADJENOVIC, 2018).

Com relação ao item “i”, o Sistema Europeu Comum de Asilo foi criado em 2013 para estabelecer padrões mínimos comuns ao tratamento de solicitantes de asilo ${ }^{6}$. Um dos principais pontos da reforma é a alteração do Regulamento de Dublin, uma vez que este determina a permanência do refugiado no Estado membro no qual ele ingressou em território europeu ${ }^{7}$ Essa circunstância tem se revelado a fonte da sobrecarga de problemas para os Estados de entrada de tais fluxos, principalmente Itália e Grécia (ATASSANOV; RADJENOVIC, 2018, p. 4, 6).

Ocorre que tal modificação é objeto de complexas discussões políticas, uma vez que implica o compartilhamento da responsabilidade de receber refugiados entre os demais Estados membros, e muitos se recusam a recebê-los. Ou seja, forma-se um cenário no qual há Estados membros com alto número de imigrantes em relação aos demais, e aqueles que não se dispõem a aceitar qualquer imigrante, gerando a possibilidade de fechamento das fronteiras internas (HAMPSHIRE, 2016, p. 546-547).

Já em relação ao item “ii”, as justificativas utilizadas pela UE para reforçar as fronteiras externas são as seguintes: o frágil controle existente nas fronteiras externas permitiu a entrada desmesurada de migrantes irregulares, causando a retomada do controle das fronteiras internas entre vários Estados membros, bem como o surgimento de ataques terroristas, os quais estariam relacionados às deficiências na vigilância fronteiriça. Neste aspecto, propõe-se a reforma do Código das Fronteiras Schengen, com destaque à Emenda que entrou em vigor em 15 de março de 2017, prevendo a obrigação dos Estados membros de realizar checagens sistemáticas em todas as pessoas, inclusive naquelas que possuem o direito de livre circulação, como cidadãos europeus e seus familiares (ATASSANOV; RADJENOVIC, 2018, p. 4, 14).

\footnotetext{
${ }^{6}$ Na América Latina, refúgio e asilo são institutos diferentes. Nesse sentido, o asilo surge do costume internacional e consiste em ceder proteção para alguém que esteja sofrendo perseguição por razões políticas, tendo o Estado poder discricionário para concedê-lo ou não. O refúgio faz parte do sistema de proteção da ONU, por meio do ACNUR, e para ser refugiado deve se enquadrar no conceito da Convenção para o Estatuto dos Refugiados de 1951 e do Protocolo adicional de 1967. Porém, nos demais países são considerados sinônimos.

${ }^{7}$ Isso quer dizer que após o imigrante que solicitou o refúgio obter seu status de refugiado, ele deve permanecer no mesmo Estado membro que lhe concedeu tal proteção nos termos da Convenção de Genebra - Convenção para o Estatuto dos Refugiados de 1951.
} 
O item “iii” se refere à assistência mútua para com terceiros Estados, destinada a atacar as causas da migração, em termos políticos e financeiros. Assim, procura reduzir os incentivos da migração irregular, desenvolvendo a cooperação com os países de origem dos fluxos migratórios, para combater a atuação dos contrabandistas de pessoas migrantes e dos traficantes de seres humanos (ATASSANOV; RADJENOVIC, 2018, p. 5, 22).

Diante dessa nova estratégia da UE destinada a responder à “crise migratória”, verifica-se que a lógica empregada - vinculada ao fechamento das fronteiras - deposita na migração a causa de problemas socioeconômicos a serem combatidos. Esse raciocínio continua potencializando barreiras à própria liberdade de circulação dos cidadãos europeus. Como exemplo, somente no ano de 2018, de janeiro a dezembro, entre aqueles que suspenderam e já retornaram e aqueles em que ainda se encontra suspenso o Acordo de Schengen, houve a retomada do controle das fronteiras internas por França, Áustria, Alemanha, Dinamarca, Suécia, Noruega, Finlândia e Polônia (EUROPEAN COMISSION, 2019).

Ou seja, a "comunitarização" do Tratado de Lisboa surge em um momento de aumento exacerbado dos fluxos migratórios, e tenta implantar uma política migratória comum após décadas de intergovernabilidade no tema e de uma política xenófoba e restrita aos interesses nacionais. Não houve uma tradição de política migratória europeia voltada à receptividade de imigrantes, o que refletiu diretamente no colapso dessa política quando se tentou “comunitarizar” o tema em um momento de crise migratória.

\subsection{A HERANÇA DO COLONIALISMO NA POLÍTICA MIGRATÓRIA PARA OS IMIGRANTES DO SUL GLOBAL}

A política migratória europeia, conforme se verificou, é desenvolvida a partir de uma lógica de segurança nacional e proteção das fronteiras externas em relação aos imigrantes de terceiros Estados. Ainda, verifica-se que essa lógica é agravada quando se trata de imigrantes vindos do Sul Global, por meio de uma rígida política de vistos e de outros requisitos que acabam impedindo a entrada de pessoas em situação de vulnerabilidade ou puramente em razão de sua nacionalidade. Todos os aspectos até agora apresentados demonstram uma política migratória xenófoba, mas cabe analisar de que forma é nutrido o sentimento xenófobo e por que ele é mais agressivo em relação aos 
imigrantes do Sul Global, o que deve ser realizado em conjunto com o estudo do nacionalismo. Tratase de tema complexo e extenso, que não se tem a pretensão de aqui esgotar.

De acordo com Benedict Anderson (2008), o nacionalismo é um fenômeno da Modernidade, que surge no século XVIII, com o Iluminismo e as revoluções iniciadas na Europa contra as monarquias absolutistas. Ou seja, ele surge a partir da formação dos Estados-Nação, os quais possuem características extremamente diversas das antigas monarquias, reinos e dinastias (ANDERSON, 2008, p. 30). Para Benedict Anderson (2008, p. 32, grifo do autor), a nação pode ser conceituada como:

Uma comunidade política imaginada - e imaginada como sendo intrinsecamente limitada e, ao mesmo tempo, soberana. Ela é imaginada porque mesmo os membros da mais minúscula das nações jamais conhecerão, encontrarão ou nem sequer ouvirão falar da maioria de seus companheiros, embora todos tenham em mente a imagem viva da comunhão entre eles.

A ideia de nação soberana se dá em razão dos ideais revolucionários da Modernidade, que questionavam a fonte de legitimidade dos reinos hierárquicos, a ordem divina. Assim, a ideia de Estado soberano é a de que não há nenhuma ordem divina acima deste, sendo ele uma forma de liberdade. A outra característica da nação é a ideia de horizontalidade, em contraposição com a verticalidade das monarquias. Ou seja, o Estado-Nação traz uma ideia de fraternidade entre os seus membros, que não são mais servos, mas, sim, cidadãos nacionais, o que desperta um sentimento de apego, independentemente de todas as desigualdades e formas de exclusão que possam existir dentro dessa nação. Em razão disso, a ideia de nacionalidade, cidadão nacional, confere legitimidade política para o Estado (ANDERSON, 2008, p. 28, 34).

A partir disso, Benedict Anderson (2008) trata do nacionalismo por meio do sentimento das pessoas em relação a pertencer a uma nação. O nacionalismo consegue captar os anseios e as esperanças das pessoas porque ele é uma construção cultural, que ao longo dos anos foi ganhando uma profunda legitimidade emocional. Tal apego se tornou tão forte que, nos séculos seguintes, diversas pessoas mataram e morreram por suas nações durante as guerras. Tais sacrifícios, advindos do apego emocional em relação à sua nação, têm sua explicação nas raízes culturais do nacionalismo (ANDERSON, 2008, p. 30, 34).

A fim de compreender o fenômeno, o autor traça uma comparação do nacionalismo com a religiosidade, explicando como esta pautava os antigos reinos, e o quanto isso foi atacado a partir do racionalismo da Modernidade. A religiosidade sempre trouxe respostas para o sofrimento humano, conferindo explicações para tudo aquilo de negativo e cruel que ocorre em nossas vidas, 
especialmente transformando a fatalidade em continuidade, mediante suas ideias do pós-vida (ANDERSON, 2008, p. 34-36).

Com a chegada do Iluminismo e seu secularismo racionalista na Europa Ocidental, o pensamento religioso foi adormecido, porém, os mesmos sentimentos humanos que dependiam deste, seguiram existindo. Benedict Anderson (2008) não sustenta que o nacionalismo veio para substituir a religiosidade, até porque ela sobrevive de maneira forte ainda hoje, mas, sim, que um dos fatores que mais contribuiu para a transformação da fatalidade em continuidade, a partir dos tempos modernos, foi o nacionalismo (ANDERSON, 2008, p. 37-38). Assim, busca propor “o entendimento do nacionalismo alinhando-o não a ideologias políticas conscientemente adotadas, mas aos grandes sistemas culturais que o precederam, e a partir dos quais ele surgiu, inclusive para combatê-los” (ANDERSON, 2008, p. 39).

Entretanto, apesar de não ter surgido de uma ideologia política específica, o nacionalismo foi sendo moldado ao longo do tempo para propósitos políticos e ideológicos, e mostra sua presença principalmente após a independência de Estados do continente americano, os quais estavam se libertando do colonialismo europeu (ANDERSON, 2008, p. 30). Assim, verifica-se que o nacionalismo surge com o Estado-Nação colonial/moderno. Por sua vez, ele foi sendo moldado ao longo do tempo, ao passo que existem diversas formas de o nacionalismo se expressar, o que traz diferentes "tipos" de nacionalismo. Como exemplo, pode existir um nacionalismo de ditaduras, que prega uma política de isolamento em relação aos demais Estados-Nação, mas ao mesmo tempo pode haver um nacionalismo de valorização das tendências autonomistas do Estado, o que foi praticado, por exemplo, por muitos governos de países latino-americanos em desenvolvimento, na busca de fortalecimento no cenário internacional pós-colonial.

$\mathrm{Na}$ presente década, vem se observando um crescimento do nacionalismo, por meio de discursos populistas de partidos de extrema direita, que tratam o Estado-Nação como propriedade, que é o que vem ocorrendo na Europa, conforme será contextualizado na segunda parte deste artigo. Tal propriedade é pertencente aos nacionais de determinado Estado; logo, o cidadão nacional, instigado pelos discursos populistas, tende a enxergar no imigrante a ameaça ao seu direito de propriedade. Assim, a proteção dessa propriedade se dá por meio do fechamento da fronteira. Diante disso, esse nacionalismo contribui para o sentimento xenófobo, que aqui se traduz em uma forma de temor ou medo de perder seus direitos e sua propriedade em relação ao estrangeiro, podendo ser destacado o recorrente temor do "roubo" de empregos (FIGUEIRA, 2018). Logo, verifica-se que os conceitos de xenofobia e nacionalismo estão intrinsicamente entrelaçados. Como diz Gustavo Pereira (2014, p. 90), “quando se reforça o culto à nação, fragiliza-se a estrangeiridade”. 
Porém, a xenofobia, em especial na Europa, ocorre de maneira mais profunda do que isso, uma vez que é marcada pelo racismo. Nesse sentido, a xenofobia se intensifica quando os imigrantes são marcados por características étnicas, de idioma, culturais ou religiosas, diversas das dos cidadãos nacionais. Ou seja, as “diferenças físicas e culturais entre a grande parte dos europeus e a maioria dos refugiados são manipuladas por grupos de direita, na construção de um discurso de medo. Teme-se a dissolução da identidade cultural [...]” (FIGUEIRA, 2015).

Entretanto, a xenofobia não surge com tais grupos de extrema direita, mas, sim, é explorada por eles para intensificar preconceitos na sociedade contemporânea. A fim de compreender a dimensão racial da xenofobia europeia, deve-se voltar no tempo e encontrar suas raízes, o que demanda compreender a lógica da colonialidade. Ao passo que o colonialismo é um processo de poder, a colonialidade é o exercício desse poder nas relações de dominação colonial, a qual permanece mesmo após o fim do colonialismo, sob a forma de neocolonialismo global ou colonialismos internos (BRAGATO, 2014, p. 211-212). Dizer que a colonialidade existe até hoje, significa dizer que o período que se vive atualmente é o da colonialidade global, no qual, ainda que a maior parte das colônias tenha conquistado sua independência política, a dominação europeia e euro-americana continua sobre os povos não europeus, por meio da divisão internacional do trabalho e do acúmulo de capital mundial (BRAGATO, 2016, p. 1.812).

A partir da modernidade/colonialismo estabeleceram-se novas identidades e uma classificação social, a qual colocou os seres humanos em diferentes posições hierárquicas, fazendo com que as relações humanas fossem verticalizadas. Isso se deu mediante a concepção dominante de direitos humanos, que surgiu no contexto dos movimentos políticos ingleses, franceses e americanos, nos séculos XVII e XVIII. Essa concepção tem como característica atribuir uma essência comum a todos os seres humanos, a qual permite afirmar a sua superioridade em relação aos demais seres, que se dá por meio da razão. Porém, aqui o significado de racional não é somente ser um ser pensante e inteligente, mas, sim, pensar e raciocinar livre das emoções e orientado ao domínio e à instrumentalização do mundo, o que é característica cultural das sociedades industriais europeias. Isso impõe que os seres humanos não sejam todos livres e iguais, que pode haver hierarquia entre eles (BRAGATO, 2014, p. 206-208, 221-222).

Logo, o conceito moderno de racionalidade exclui o homem não europeu, pois todos aqueles que fogem aos padrões racionais europeus, ou seja, pensam e se relacionam de forma diversa, são caracterizados como irracionais, bárbaros, selvagens. Tal discurso de superioridade ocidental europeia se inicia com os humanistas do Renascimento europeu, que se utilizaram de uma definição de homem e de humano a qual excluiu muitos seres humanos. Então é um discurso que define 
humanidade, mas exclui a maioria da própria humanidade e a coloca em categorias hierárquicas (BRAGATO, 2016, p. 1.810-1.811).

Isso porque, a partir da ideia de conquista do colonialismo, o colonizador não enxerga o outro como outro de si mesmo, o outro é negado e, portanto, obrigado a sujeitar-se ao dominador. Essa diferença colonial é importante de ser aqui observada, pois é nesse momento que se inicia a relação com o outro, o estrangeiro. Ou seja, a primeira relação foi de violência, entre conquistador e conquistado, surgindo aqui a ideia de superioridade do Eu europeu em relação ao outro primitivo. O outro já inicia a relação tendo a sua dignidade negada (DUSSEL, 1993, p. 43-49).

Nesse sentido, a noção de transmodernidade de Enrique Dussel, que entra na questão da colonialidade, explica que a Europa desenvolveu um mundo periférico, representado pelas colônias, onde se situam as vítimas irracionais da Modernidade, o índio sacrificado, o negro escravizado, etc. A partir disso é que se torna enraizada na população uma visão que, provocada por discursos desumanizantes, faz nascer o preconceito e a discriminação em relação a outros seres humanos que se situam nesse mundo periférico das colônias (BRAGATO, 2016, p. 1.813-1.814). Isso explica o sentimento xenófobo do europeu em relação ao imigrante, em especial aquele do Sul Global, das antigas colônias, do mundo subdesenvolvido.

Tudo isso é reforçado pela política migratória europeia desenvolvida na contemporaneidade, a qual perpetua esses processos de colonialidade, mediante a hierarquização das categorias de pessoas na atribuição de requisitos para circular e ter direitos dentro do território europeu. Assim, mesmo com a política migratória desenvolvida no âmbito supranacional, foram reproduzidas as diferenças raciais, entre europeus e não europeus, ex-colonizados e ex-colonizadores, por meio de linhas abissais (SILVA; PISETA, 2019, p. 30-31). Nesse sentido, a partir da lógica da colonialidade, estabeleceu-se uma relação específica da Europa com o resto do mundo, cabendo citar sobre o tema o que diz Boaventura de Souza Santos (2014, p. 11-12):

Concebo as versões dominantes da modernidade ocidental como construídas a partir de um pensamento abissal, um pensamento que dividiu o mundo entre sociedades metropolitanas e coloniais. [...] os direitos humanos foram historicamente concebidos para vigorar apenas do lado de cá da linha abissal, nas sociedades metropolitanas. [...] com o fim do colonialismo histórico, continua sob outras formas [...].

Então, as sociedades de um lado da linha eram consideradas o mundo desenvolvido, racional e progressista, ao passo que do outro lado se tinha o mundo subdesenvolvido, primitivo, onde só há espaço para violência e desordem (BRAGATO, 2014, p. 213). Isso se reflete na nova categorização e hierarquização feita pela política migratória europeia, a qual funciona da seguinte maneira: em um primeiro nível situam-se os cidadãos europeus, que desfrutam plenamente de seus direitos de livre 
circulação, para em um nível inferior situarem-se imigrantes de alta qualificação, sendo uma espécie de elite dos imigrantes de terceiros Estados, que possuem direitos, mas de forma bem mais limitada, e por fim, na base da pirâmide, encontram-se os refugiados, solicitantes de asilo e migrantes irregulares, cujos direitos são nulos ou praticamente nulos (SILVA; PISETA, 2019, p. 47-51). Isso demonstra que

Enquanto a política identitária busca ressaltar a igualdade a partir do reconhecimento da alteridade entre cidadãos europeus, sua política migratória é reforçada pelo padrão colonial de poder, por intermédio de um ceticismo misantrópico quanto às capacidades de integração da pessoa migrante, subalterizando-a [sic] (SILVA; PISETA, 2019, p. 46).

Assim, verifica-se a existência de uma política migratória contraditória com os princípios e direitos humanos presentes tanto no Direito da UE, quanto nos tratados internacionais por ela firmados e disseminados pelo resto do mundo como "universais”.

\section{O CRESCIMENTO DO NACIONALISMO E DA XENOFOBIA NA UNIÃO EUROPEIA EM TEMPOS DE CRISE MIGRATÓRIA E A AMEAÇA DO EUROCETICISMO}

A crise migratória pela qual o mundo está passando é a maior da história, já tendo ultrapassado em grande número a quantidade de refugiados da Segunda Guerra Mundial. Pelo sétimo ano consecutivo o número de migrantes forçados aumenta, chegando em 2018 ao total de 70,8 milhões (ACNUR, 2018, p. 4). Portanto, é possível sim falar em crise migratória, mas é preciso tomar cuidado quando se fala especificamente sobre a crise migratória pela qual a UE estaria passando por conta do aumento dos fluxos migratórios.

Isso porque deste total de migrantes forçados, 41,3 milhões são deslocados internos, ou seja, deslocaram-se para outras regiões dentro de seu próprio país. Ainda, os países em desenvolvimento concedem acolhida a um terço dos refugiados que se enquadram no sistema internacional de proteção do ACNUR, enquanto os desenvolvidos acolhem somente 16\%. A maioria dos refugiados tem vindo dos seguintes países: Síria, Afeganistão, Sudão do Sul, Myanmar e Somália. Já os cinco países que mais recebem imigrantes são Turquia, Paquistão, Uganda, Sudão e Alemanha, esta última representando o primeiro país desenvolvido a figurar entre os cinco maiores acolhedores desde o início da “crise migratória” (ACNUR, 2018, p. 2-3).

Isso demonstra que os Estados membros da UE não estão sendo o grande alvo prejudicado pela crise. Assim que os fluxos migratórios começaram a aumentar, a partir da Primavera Árabe, em 2011, a UE já começou a colocar em prática uma política de fechamento de fronteiras que com o passar dos últimos anos vem ficando cada vez mais forte, por conta de movimentos nacionalistas, 
impulsionados pela xenofobia. Nesse sentido, a segunda parte deste estudo irá analisar como esse cenário pode apresentar ameaças ao futuro do bloco europeu.

\subsection{O CRESCIMENTO DO EUROCETICISMO E O FENÔMENO DO BREXIT: MOTIVAÇÕES E IMPACTOS}

O euroceticismo é um fenômeno que existe desde os primórdios do processo de integração europeia. Trata-se de uma oposição em relação a esse esquema de integração supranacional, seja por razões políticas, econômicas ou identitárias. Em especial, podem ser destacadas quatro raízes principais para o surgimento desse fenômeno: democracia, soberania nacional, economia e identidade nacional. O euroceticismo pode se situar nos dois campos opostos do espectro político, ou seja, há políticos eurocéticos de esquerda e de direita, porém, as motivações para o euroceticismo são diferentes nos dois lados. O ponto em comum é que ambos estão centrados no discurso populista. O euroceticismo que toca o tema que aqui se discute é aquele advindo da extrema direita, pois este foca na identidade nacional e no discurso anti-imigração para se opor à UE (BERTONCINI; KOENING, 2014, p. 1-5; COSTA, 2017, p. 52).

No contexto recente, muitos Estados membros vêm enfrentando problemas de ordem econômica, com o aumento da taxa de desemprego, bem como com dívidas em relação à UE, o que os levou a assumirem compromissos com uma política de austeridade. Assim, a maior parte dos cidadãos europeus passou a considerar a UE como a grande responsável pela crise econômica, ainda que as instituições europeias não possuam legitimidade para interferir em políticas fiscais, orçamentárias e sociais internas dos Estados. Isso levou a um crescimento do euroceticismo, com a ascensão de políticos eurocéticos tanto em eleições da UE, quanto em nível nacional (COSTA, 2017, p. 51-52, 58).

Desse modo, o aumento dos fluxos migratórios, combinado com a crise financeira, fez crescer na população europeia o sentimento xenófobo e o euroceticismo, os quais, apesar de já existirem há muito tempo, foram exacerbados. Tal cenário foi utilizado para manobra por partidos de extrema direita, com um discurso populista anti-imigração e nacionalista, ou seja, contra a UE, os quais estão conseguindo entrar em ascensão. Tal discurso passou a criticar a UE por não controlar a entrada desses migrantes e por impor obrigações aos Estados membros a respeito do tema. Assim, apesar de diversas diferenças entre esses partidos de extrema direita, situados em vários países europeus, a oposição à imigração é um ponto em comum entre todos. Por sua vez, o apoio da 
população a esse euroceticismo traz legitimidade ao discurso anti-imigração (COSTA, 2017, p. 5152, 58; HAMPSHIRE, 2016, p. 544-545).

Exatamente isso ocorreu no Reino Unido, com a ascensão do partido político de extrema direita United Kingdom Independence Party (UKIP), o qual ganhou a maioria dos assentos britânicos nas eleições de 2014 do Parlamento Europeu (HAMPSHIRE, 2016, p. 545). É nesse contexto que, em 2015, teve início o fenômeno conhecido como Brexit, por meio do qual o Reino Unido começou o seu processo de retirada da UE, quando o então primeiro ministro britânico, David Cameron, por pressão dos eurocéticos, realizou uma promessa eleitoral, na qual dizia que se fosse reeleito, executaria um referendo com o povo britânico, acerca da saída ou permanência do Reino Unido no bloco (COSTA, 2017, p. 51-53; LABRANO, 2016, p. 45-46). No dia 23 de junho de 2016, o resultado do referendo apresentou um total de 51,9\% de britânicos que votaram pela saída do Estado (VIEIRA, 2016, p. 88).

Entre os motivos que levaram ao Brexit estão questões de ordem econômica, como as anteriormente mencionadas. Não obstante, cabe referir que a campanha a favor da retirada, encabeçada por políticos de extrema direita, valeu-se do discurso populista anti-imigração (COSTA, 2017, p. 58; VIEIRA, 2016, p. 89-90). Tal discurso anti-imigração e nacionalista conseguiu assentarse em raízes identitárias profundas do Reino Unido, que remontam ao período colonial. Desde o início, o Reino Unido é um dos Estados membros no qual o euroceticismo sempre imperou de maneira forte. Uma das principais explicações para isso é o fato de que o Império Britânico moldou o resto do mundo durante três séculos seguidos. Primeiramente, tornou-se o maior império dos tempos coloniais, quando estabeleceu colônias em todos os continentes e oceanos, entre os séculos XVII, XVIII e XIX. Ainda, apesar da conquista da independência de suas antigas colônias, durante o século XX, foi criada a Commonwealth, fazendo com que até hoje suas antigas colônias independentes permaneçam simbolicamente leais à Coroa Britânica (SZUCKO, 2018, p. 204-209; PERISIC, 2010, p. 2-4).

Essas circunstâncias foram suficientes para que os britânicos se sentissem superiores em relação aos demais povos, inclusive europeus. Isso fez com que fosse criada uma barreira psicológica em relação ao fato de participar da integração europeia e, ainda, ceder sua soberania para as instituições comunitárias, acreditando-se que com isso o Reino Unido perderia sua influência. Essa mesma barreira psicológica também é responsável pela dificuldade de os britânicos se identificarem enquanto cidadãos europeus (SZUCKO, 2018, p. 204-209; PERISIC, 2010, p. 2-4).

Isso posto, retorna-se à sequência de acontecimentos que levaram ao Brexit. Antes de ser iniciado o procedimento oficial de saída do Reino Unido, David Cameron renunciou, assumindo, na 
sequência, Theresa May, como nova primeira-ministra, demonstrando uma postura totalmente favorável ao Brexit, indo ao encontro das manifestações contrárias à imigração (LABRANO, 2016, p. 46).

O discurso anti-imigração, portanto, contribuiu para um evento histórico inesperado: o início de um procedimento de saída de um Estado membro da UE. Porém, vários sinais poderiam prever a possibilidade de uma futura saída do Reino Unido. O primeiro sinal seria o fato de que o Reino Unido sempre participou da integração europeia de maneira menos profunda que os demais países; por exemplo, com a sua não participação no Acordo de Schengen, na PESC e na Zona do Euro (LABRANO, 2016, p. 46-47).

Ainda, esta não foi a primeira vez que o Reino Unido realizou um referendo acerca de sua saída ou permanência no bloco europeu, pois em 1975 foi convocado pelo governo britânico o mesmo referendo em relação à Comunidade Econômica Europeia (CEE). Entretanto, naquela época, 67\% da população votou pela permanência, em um resultado contrário ao de 2016 (VIEIRA, 2016, p. 89-90). Ademais, antigos e reiterados confrontos entre UE e Reino Unido fizeram a população mais idosa votar favoravelmente à saída (LABRANO, 2016, p. 46).

Como se pode observar, o fenômeno do Brexit traz uma série de consequências que debilitam o bloco europeu, pois o Reino Unido é a segunda economia mais forte da UE, atrás somente da Alemanha. Ainda, para além dos efeitos econômicos, o Brexit causa efeitos políticos, constitucionais e diplomáticos para a UE, os quais podem se estender por pelo menos uma década. Ademais, causa efeitos jurídicos, pois deverão ser reavaliados todos os tratados firmados entre Reino Unido e UE, os tratados entre a UE e terceiros Estados, bem como todo o direito comunitário europeu que foi transposto ao direito britânico (VIEIRA, 2016, p. 99). Por fim, também causa efeitos indiretos, como uma intensa fragmentação popular e a possibilidade de um novo referendo sobre a independência da Escócia e da Irlanda do Norte (LABRANO, 2016, p. 48-51).

Claro está que são inúmeras as consequências prováveis, o que torna o fenômeno do Brexit algo tão importante de ser analisado e estudado, na medida em que “os possíveis reflexos de uma efetiva saída do Reino Unido da União Europeia configurariam, seguramente, uma nova ordem mundial. Desde a queda do Muro de Berlim, em 1989, não se tem falado de uma conformação distinta da Europa (des) integrada”8 (VIEIRA, 2016, p. 91, tradução nossa).

\footnotetext{
${ }^{8}$ No original: "Los posibles reflejos de una efectiva salida del Reino Unido de la Unión Europea configurarían, seguramente, un nuevo orden mundial. Desde la caída del Muro de Berlín, en 1989, no se ha hablado de una conformación distinta de la Europa (des) integrada.”
} 
Além de todas essas consequências, o Brexit representa um precedente para os demais Estados membros, em especial para aqueles que estejam vivenciando um aumento do nacionalismo e da xenofobia. Logo após o referendo, Estados fundadores como França e Itália, presentes desde 1951 no bloco europeu, também começaram a questionar a sua permanência no sistema integrado (VIEIRA, 2016, p. 92), representando, portanto, mais uma forte ameaça ao futuro da UE.

\subsection{O CENÁRIO POLÍTICO ATUAL DA UNIÃO EUROPEIA: UMA ANÁLISE DO CASO ITALIANO}

A partir do exposto, é preciso analisar a possibilidade de outros Estados membros retiraremse do bloco, pois são vários os países europeus com governos e líderes extremistas anti-imigração, sustentando uma saída da UE, conduta permitida pelo artigo 50 do TUE, como, por exemplo, o líder Viktor Orbán, na Hungria.

Ressalta-se que as últimas reuniões do Conselho Europeu foram marcadas por discussões complexas acerca do tema da migração, havendo uma divisão entre os Estados membros que ainda mantêm um posicionamento pró-UE e mais voltado à receptividade de refugiados - como é o caso de Portugal - e aqueles com atitude nacionalista e xenófoba. Nesse sentido, afirmou Antônio Costa, primeiro-ministro de Portugal, na Reunião do Conselho Europeu de setembro de 2018, que:

No tema das migrações é manifesto que ou há uma resposta à escala europeia, ou todas as respostas são insuficientes [...] É também o tema onde mais se manifesta a enorme contradição daqueles que têm uma abordagem nacionalista [...] nacionalismo é a impotência de resolver os problemas que só em conjunto podem ser resolvidos (UNIÃO..., 2018).

Como se tem observado, em que pese a manifestação do primeiro-ministro português, há um crescimento acentuado do nacionalismo e da xenofobia na Europa, alcançando Estados de todas as partes da UE. Diante desse cenário, o caso da Itália é interessante de ser analisado, pois este país é um dos membros fundadores do sistema comunitário europeu, e que está sendo liderado por partidos nacionalistas e anti-imigração, em decorrência das eleições de 2018. Ademais, a Itália compõe um dos países que são abrangidos pelo mar Mediterrâneo, canal pelo qual chegam a maioria dos imigrantes à Europa. De acordo com dados da Organização Internacional para as Migrações (OIM), o mar Mediterrâneo foi considerado a fronteira mais mortífera do mundo. Apesar do trabalho incansável das ONGs, além de as organizações da sociedade civil não serem suficientes para salvar todas essas vidas, elas se deparam com leis e medidas contrárias dos governos, os quais levantam novas barreiras ou até mesmo criam punições legais para quem ajudar imigrantes (PÉREZ ESPIGARES, 2018, p. 172-173). 
De acordo com dados do ACNUR, apesar de o número de imigrantes que atravessam o mar Mediterrâneo ter diminuído em comparação a 2016, ainda há um alto número de pessoas que arriscam suas vidas nessa travessia, chegando a maioria pela Itália, a qual contou com 126.500 pedidos de asilo em 2017 (ACNUR, 2018, p. 7). Nesse sentido, foram criadas na UE cotas para acolhida de imigrantes, as quais determinam que os demais Estados membros recebam certas porcentagens de pessoas vindas da Itália e da Grécia, países abrangidos pelo mar Mediterrâneo, o que veio com a nova estratégia de política migratória europeia pós-aumento dos fluxos, conforme visto na primeira parte deste artigo. Porém, somente 25\% das cotas foram efetivamente assumidas (PÉREZ ESPIGARES, 2018, p. 173). Diante disso, verifica-se que os países situados na região abrangida pelo mar Mediterrâneo acabam por receber mais imigrantes, mas também são os Estados nos quais o nacionalismo e a xenofobia podem crescer de maneira mais alarmante.

O cenário político italiano atual não é nada favorável à imigração ou à integração europeia. Nas eleições legislativas de março de 2018, os partidos MoVimento 5 Stelle e Lega Nord foram os mais votados e, consequentemente, formaram uma coalizão, da qual saiu como primeiro ministro Giuseppe Conte. Ambos os partidos são anti-imigração e, conforme era previsto, a possibilidade de a Itália sair da Zona do Euro era esperada somente no caso de estes dois partidos formarem essa coalizão. Isso representa uma forte ameaça à UE, pois com a saída do Reino Unido, a Itália torna-se a terceira economia do bloco (VOLTA..., 2018).

A vitória de partidos como esses demonstra o sentimento nacionalista e xenófobo que está disseminado entre os cidadãos italianos. Uma pesquisa de 2016, do Instituto Ipsos Mori, às vésperas do Brexit, revelou que 58\% da população italiana era a favor de realizar o mesmo referendo, e 48\% votaria pela saída. Na mesma pesquisa, a Itália liderou o ranking de Estados membros em que a população apoiaria uma saída da UE (HALF..., 2016).

No cenário pós-eleições italianas de 2018, não somente a população estaria inclinada a isso, mas agora a maioria no governo também. Alguns meses depois, em junho de 2018, a Itália fechou suas portas para embarcações de resgate a imigrantes que chegavam pelo mar Mediterrâneo, decisão tomada pelo ministro do interior, Matteo Salvini, do partido Lega Nord, o qual lidera as pesquisas de opinião do país (KINGSLEY, 2018).

Ainda, apesar das inúmeras divergências, todos os Estados membros da UE, no dia 29 de junho de 2018, durante reunião do Conselho Europeu, chegaram a um acordo para a criação de “centros de triagem” dentro do território europeu, para os quais os imigrantes que chegarem à Europa pelo mar serão levados. Nesses centros haverá uma triagem, cujo objetivo é separar aqueles que se 
enquadram no status de refugiado daqueles considerados migrantes econômicos, a fim de que estes últimos sejam devolvidos ao seu país de origem (ABELLÁN; PÉREZ, 2018).

Registra-se, entretanto, que a comprovação de que a pessoa se enquadra no conceito de refugiado é extremamente difícil, tendo em vista que quem foge às pressas muitas vezes não porta sequer um documento de identidade (PEREIRA, 2014, p. 22), além das questões que envolvem a qualificação de refugiado segundo o ACNUR global, o qual adota uma antiga definição utilizada para refugiados europeus da Segunda Guerra Mundial, diversa dos motivos pelos quais os solicitantes de refúgio fogem de seus países, atualmente ${ }^{9}$. Essa qualificação nega as ampliações do conceito de refúgio trazidas pela América Latina e África, o que revela novamente a presença da colonialidade no tema migratório na comunidade internacional do Norte Global. Ademais, há uma discussão acerca de até que ponto os migrantes econômicos podem ser considerados migrantes voluntários ou forçados, em razão da situação de pobreza extrema que podem estar sofrendo em seus países de origem. Logo, a perspectiva que se enxerga a partir disso é a de devolução de milhares de migrantes aos seus países de origem, onde muitas vezes correm risco de vida.

Feitas as ressalvas, o referido acordo recém-firmado pelo bloco europeu estabelece que tais centros só serão construídos por aqueles Estados membros que voluntariamente o fizerem, eliminando, assim, as cotas obrigatórias de distribuição anteriormente mencionadas, beneficiando aqueles países europeus que se negam a receber qualquer refugiado ou imigrante (ABELLÁN; PÉREZ, 2018), deixando a questão migratória sob os interesses nacionais e fora do escopo do sistema comunitário. A UE, neste novo plano, limitar-se-ia a financiar os centros daqueles Estados membros que decidirem por construí-los em seus territórios (ABELLÁN; PÉREZ, 2018). Assim, verifica-se o retorno do tema migratório à intergovernamentalidade, retrocedendo em relação à reforma do Tratado de Lisboa.

Outro ponto do Acordo simboliza que a UE ainda segue com uma política de fechamento de fronteiras, ao estabelecer a criação de plataformas de desembarque de imigrantes fora do território europeu, em outros países do norte da África, como a Líbia, a fim de evitar a travessia para os países europeus (ABELLÁN; PÉREZ, 2018). Ainda, os próprios Estados membros da UE sinalizaram para as ONGs de resgate que estas não impeçam a atividade dos guardas costeiros líbios.

\footnotetext{
${ }^{9}$ A Convenção de 1951 foi criada com o objetivo de estabelecer proteção aos refugiados provenientes da Segunda Guerra Mundial na Europa, contendo um conceito específico de refugiado. O Protocolo de 1967 extinguiu as referidas limitações geográficas e temporais, mas seguiu com o mesmo conceito, vigente até hoje, que não mantém relação com os motivos pelos quais as pessoas de outras regiões solicitam refúgio na atualidade. Ainda, as ampliações do conceito realizadas na América Latina e na África não foram adotadas pelo ACNUR global.
} 
Logo após a celebração do referido acordo, no dia $1^{\circ}$ de julho de 2018, um barco com imigrantes resgatados da Líbia por uma ONG se deparou com fronteiras fechadas na Itália e em Malta. Os referidos países recusaram-se a receber a embarcação em seus portos, não sendo esta a primeira vez que a Itália impede a entrada de imigrantes em seu território, em 2018 (BARCO..., 2018), comportamento que vem sendo seguido em 2019.

Tudo isso revela que a perspectiva segue não sendo apropriada para o futuro do bloco europeu, que continua com a mesma política migratória há anos, retrocedendo ao tratamento intergovernamental, o qual tende a piorar com o crescimento do nacionalismo e da xenofobia, especialmente em países tão importantes para a UE como a Itália, membro fundador e quarta economia do sistema comunitário europeu.

\section{CONSIDERAÇÕES FINAIS}

O presente artigo buscou analisar se o crescimento do nacionalismo e da xenofobia, na UE, poderia representar uma ameaça ao futuro do bloco europeu.

Na primeira parte deste estudo foi explorada a história da liberdade de circulação dos cidadãos europeus e a trajetória da política migratória europeia para imigrantes extra comunitários. Verificou-se que a livre circulação de pessoas constitui um dos elementos essenciais para a UE atingir seus objetivos econômicos. Ao mesmo tempo, foi constatado que o reconhecimento da cidadania europeia e a eliminação das fronteiras internas para estes cidadãos causaram impacto na política migratória para imigrantes extra comunitários, reconhecendo plenos direitos aos europeus de um lado, e de outro fortalecendo as fronteiras externas, violando direitos dos imigrantes de terceiros Estados.

Nessa linha, buscou-se compreender o porquê da existência de uma política migratória xenófoba, principalmente em relação aos imigrantes do Sul Global. As explicações residem, primeiramente, no surgimento do nacionalismo a partir da formação do Estado-Nação de padrão colonial. Do mesmo modo, verificou-se que a xenofobia surge nesse contexto da modernidade/colonialismo, momento a partir do qual a Europa dividiu o mundo por uma linha abissal, entre mundo periférico, nas colônias, e mundo desenvolvido, na Europa. Tal divisão sustentou discursos desumanizantes em relação aos habitantes do mundo periférico, chamado de Sul Global, que permanecem ensejando a discriminação ainda na contemporaneidade, pela presença da colonialidade, que pauta as relações de poder e domínio entre Norte e Sul Global. 
A partir desta lógica xenófoba e colonial da política migratória desenvolvida pela UE, foram verificados vários aspectos não positivos para o próprio bloco. O primeiro deles é o caráter intergovernamental dado ao tema, que permite aos Estados membros agirem de acordo com seus interesses nacionais, fragilizando a supranacionalidade da UE. O segundo é a incompatibilidade da política migratória produzida pelos países europeus com os princípios previstos nos tratados constitutivos da UE, bem como nos tratados internacionais ratificados pelo bloco. O terceiro é que uma política desenvolvida a partir de uma lógica xenófoba estimula o estabelecimento de barreiras à livre circulação de pessoas, como os mencionados casos de suspensão do Acordo de Schengen.

Na segunda parte deste artigo foi contextualizado o cenário atual da chamada crise migratória, a fim de analisar como este aumento nos fluxos migratórios, somado ao crescente nacionalismo e xenofobia, causaram o fortalecimento do euroceticismo. Primeiramente foi estudado o fenômeno do Brexit, que teve como um de seus principais motivos a imigração, e que deixa uma série de consequências negativas para o bloco europeu. Do mesmo modo, verificou-se que o Brexit trouxe um precedente perigoso para os demais Estados membros que presenciam o aumento dos discursos anti-imigração. Neste sentido, constatou-se que a Itália é um desses países, que conta com um crescente movimento nacionalista e xenófobo nos últimos anos, fazendo com que grande parte da população deseje a saída do país da UE, elegendo partidos anti-imigração, que atualmente estão no governo.

O fim da integração europeia é algo improvável, mas a possibilidade de sua fragmentação é evidente e os primeiros passos já estão sendo dados nesse sentido. A maneira xenófoba e colonialista da Europa de atuar fez com que os movimentos nacionalistas anti-imigração de extrema direita ganhassem força em um contexto de crise migratória, e influenciassem muitos Estados membros a recuarem na política migratória europeia comum e a adotarem a imposição de barreiras à livre circulação de pessoas, um dos pilares da união econômica e monetária.

O Brexit foi o primeiro exemplo, mas que pode ser seguido pela Itália, país que não possui a mesma tradição britânica eurocética, pois foi um dos Estados fundadores da integração europeia, que historicamente participou da UE de forma mais ativa, como sendo integrante da Zona Schengen, mas que agora está sendo governado por partidos eurocéticos. Essa é, portanto, uma ameaça concreta ao futuro da UE, confirmando, dessa forma, a hipótese de trabalho apresentada como resposta ao problema de pesquisa que guiou a realização deste estudo. Diante desse cenário, deve haver uma reflexão sobre as bases da política migratória europeia, que deve se pautar nas demandas do mundo contemporâneo e romper com a xenofobia e com as classificações raciais hierárquicas do período colonial. 


\section{REFERÊNCIAS}

ABELLÁN, Lucía; PÉREZ, Claudi. UE sela pacto para criação de “centros de triagem” de imigrantes. El País, 29 junho 2018. Disponível em: http://bit.ly/353psuM. Acesso em: 21 jan. 2019.

ACCIOLY, Elizabeth. MERCOSUL e União Europeia: Estrutura Jurídico-Institucional. Curitiba: Juruá Editora, 1996.

ACNUR. Global Trends Report. Genebra, 19 jun. 2018. Disponível em: https://bit.ly/356frgz. Acesso em: 8 jan. 2019.

ANDERSON, Benedict. Comunidades Imaginadas. Tradução Denise Bottman. São Paulo: Compania das Letras, 2008.

ARANGO, Joaquín. Dificultades y dilemas de las políticas de inmigración. In: Revista ARBOR, Madrid, CLXXXI, n. 713, mayo-junio, 2005.

ATASSANOV, Nikolai; RADJENOVIC, Anja. EU asylum, borders and external cooperation on migration. Recent developments. European Parliamentary Research Service (EPRS), May 2018. Disponível em: https://bit.ly/340brwN. Acesso em: 10 mar. 2019.

BARCO de resgate de migrantes vai à Espanha depois de Itália e Malta impedirem desembarque. G1 (por Reuters), 01/07/2018. Disponível em: https://glo.bo/36mHzfl. Acesso em: 21 jan. 2019.

BATISTA, Vanessa Oliveira. União Europeia: livre circulação de pessoas e direito de asilo. Belo Horizonte: Del Rey, 1998.

BERTONCINI, Yves; KOENIG, Nicole. Euroscepticism or Europhobia: Voice vs. Exit? Policy Paper, Norte Europe Jacques Delors Institute, Paris, n. 121, p. 1-20, 2014. Disponível em: https://bit.ly/2s9aapN. Acesso em: 6 ago. 2019.

BRAGATO, Fernanda Frizzo. Discursos desumanizantes e violação seletiva de direitos humanos sob a lógica da colonialidade. Quaestio Iuris, Rio de Janeiro, v. 09, n. 04, p. 1.806-1.823, 2016. Disponível em: https://bit.ly/356UzFJ. Acesso em: 16 jun. 2019.

BRAGATO, Fernanda Frizzo. Para além do discurso eurocêntrico dos direitos humanos: contribuições da descolonialidade. Revista Novos Estudos Jurídicos, v. 19, n. 1, p. 201-230, 2014. Disponível em: https://bit.ly/2E1vb8C. Acesso em: 16 jun. 2019.

COSTA, Olivier. A União Europeia e sua Política Exterior: História, Instituições e Processo de Tomada de Decisão. Brasília: Fundação Alexandre de Gusmão, 2017.

DUSSEL, Enrique. O encobrimento do Outro (ou origem do “mito da modernidade”). Tradução Jaime A. Claesen. Petrópolis: Vozes, 1993.

EUR-LEX. Ato Único Europeu. 29 junho 1987. Disponível em: http://bit.ly/358FfZe. Acesso em: 10 jan. 2019. 
EUR-LEX. Regulamento (CE) n. ${ }^{\circ}$ 539/2001 do Conselho. 15 março 2001. Disponível em: http://bit.ly/2PsrdLx. Acesso em: 15 fev. 2019.

EUR-LEX. Schengen (Acordo e Convenção). 14 junho 1985. Disponível em: http://bit.ly/346u16a. Acesso em: 16 jan. 2019.

EUROPEAN COMISSION. Temporary Reintroduction of Border Control. Migration and Home Affairs, 10 March 2019. Disponível em: http://bit.ly/2E6Th1z. Acesso em: 10 mar. 2019.

EUROPEAN COMISSION. Una nueva era para las políticas de justicia e interior de la UE. Comunicado de prensa. Bruselas, 30 de noviembre de 2014. Disponível em: http://bit.ly/355wWgP. Acesso em: 4 fev. 2019.

FIGUEIRA, Rickson Rios. Os refugiados e o dever moral das nações. In: MigraMundo, 26 de setembro de 2015. Disponível em: http://bit.ly/2E1lhDT. Acesso em: 7 mar. 2019.

FIGUEIRA, Rickson Rios. Razões da Xenofobia. Ensaio sobre os fatores contribuintes da violência xenófoba contra imigrantes e refugiados venezuelanos em Roraima. In: VON ZUBEN, Catarina et al. (org.). Migrações Venezuelanas. Campinas: Núcleo de Estudos de População "Elza Berquó”Nepo/Unicamp, 2018.

HALF of people in nine European countries believe UK will vote to leave de EU. Ipsos MORI, 9 May 2016. Disponível em: http://bit.ly/2P2e9NZ. Acesso em: 20 jan. 2019.

HAMPSHIRE, James. European migration governance since de Lisbon Treaty: introduction to the special issue. Journal of Ethnic and Migration Studies, London, v. 42, n. 4, p. 537-553, 2016. Disponível em: http://bit.ly/38jTrAJ. Acesso em: 4 ago. 2019.

JUAN, Laura García. La política de integración de inmigrantes en el nuevo Fondo de asilo, migración y integración de la Unión Europea. El caso español en el punto de mira. In: Revista Facultad de Derecho y Ciencias Políticas, Medelín, Colombia, volume 46, n. ํ 124, p. 93-115, junho/2016. Disponível em: http://bit.ly/2schot2. Acesso em: 13 jan. 2019.

KINGSLEY, Patrick. Crise de imigração na Europa já passou, mas xenofobia continua. Estadão, Internacional ([a partir de] The New York Times), 8 julho 2018. Disponível em: http://bit.ly/2PwoMrp. Acesso em: 20 jan. 2019.

LABRANO, Roberto Ruiz Díaz. La salida de un Estado Miembro en el Proceso de Integración. El Reino Unido y la Unión Europea. In: Revista de la Secretaría del Tribunal Permanente de Revisión, Año 4, n. ${ }^{\circ}$ 8, p. 41-63, agosto 2016.

NEGRO, Sandra. Derecho de la Integración. Buenos Aires: Editorial B de f, 2010.

PARLAMENTO EUROPEU. O Tratado de Lisboa. Fichas temáticas sobre a União Europeia. Maio de 2018. Disponível em: http://bit.ly/2E2nsHq. Acesso em: 4 fev. 2019.

PEREIRA, Gustavo Oliveira de Lima. Direitos Humanos e Hospitalidade. São Paulo: Editora Atlas, 2014. 
PÉREZ ESPIGARES, Pablo. Diferencia y exclusión: alergia al otro en el seno de Europa. In:

Revista Internacional de Filosofía y Teoría Social - Universidad del Zulia, Maracaibo,

Venezuela, $\mathrm{n}^{\circ}$ 80, p. 171-181, 2018.

PERISIC, Bojana. Britain and Europe: a History of Difficult Relations. Institute for Cultural Diplomacy, Berlin, March 2010. Disponível em: http://bit.ly/2seeuUB. Acesso em: 6 ago. 2019.

ROJAS-ROMAGOSA, Hugo; BOLLEN, Johannes. Estimating migration changes from the EU's free movement of people principle. CPB Netherlands Bureau for Economic Policy Analisys, 10 October, 2018. Disponível em: http://bit.ly/355ig1n. Acesso em: 10 mar. 2019.

SANTOS, Boaventura de Sousa. Se Deus fosse um ativista dos direitos humanos. São Paulo: Cortez Editora, 2014.

SILVA, Karine de Souza; PISETA, Ivan Vieira. Dois pesos e duas medidas: a projeção da colonialidade nas políticas de migração e de cidadania da União Europeia. Revista de Estudos e Pesquisas sobre as Américas, Brasília - DF, v. 13, n. 1, p. 30-60, 2019.

SILVA, Wanise Cabral; AMARAL, Nemo de Andrade do. A Imigração na Europa: a ação política da União Europeia para as migrações extracomunitárias. In: Sequência (Florianópolis), Florianópolis, n. 66, p. 235-259, julho 2013. Disponível em: http://bit.ly/346xkKC. Acesso em: 8 jan. 2019.

SZUCKO, Angélica Saraiva. Percepções Identitárias no Reino Unido: Antes e depois do referendo Britânico. Carta Internacional, Belo Horizonte, v. 13, n. 1, p. 200-223, 2018. Disponível em: http://bit.ly/2qziwGL. Acesso em: 6 ago. 2019.

UNIÃO Europeia abriu uma porta para resolver o problema da gestão das migrações. República Portuguesa, 20 de setembro de 2018. Disponível em: http://bit.ly/2Pww3aN. Acesso em: 9 mar. 2019.

VIEIRA, Luciane Klein. BREXIT: ¿Y ahora? Consecuencias jurídicas de la retirada del Reino Unido de la Unión Europea. In: Revista Peruana de Derecho Internacional, Lima, Peru, $\mathrm{n}^{0}{ }^{154}$, p. 87-104, Junio 2016.

VOLTA de Berlusconi, onda nacionalista, imigração: o que está em jogo na eleição na Itália. BBC News Brasil. 3 março 2018. Disponível em: https://bbc.in/2P3HmrD. Acesso em: 20 jan. 2019.

Vitória Volcato da Costa Mestranda em Direito Público pela Universidade do Vale do Rio dos Sinos (Unisinos) Bolsista Capes/Proex. Bacharel em Direito pela Pontifícia Universidade Católica do Rio Grande do Sul (PUCRS). Advogada.E-mail: vitoria.volcato@gmail.com

Luciane Klein Vieira Doutora em Direito Internacional pela Universidad de Buenos Aires (UBA). Mestre em Direito Internacional Privado pela UBA. Mestre em Direito da Integração Econômica pela Universidad del Salvador e Université Paris 1 - Pantheón - Sorbonne. Professora pesquisadora no Programa de Pós-Graduação em Direito da Universidade do Vale do Rio dos Sinos (Unisinos).E-mail: lucianekleinvieira@yahoo.com.br 